\title{
MURABAHAH FINANCING AND EFFECT ON EARNINGS IJARAH BCA ISLAMIC YEAR 2012-2015
}

\author{
Agus Arwani \\ Faculty of Islamic Economics and Business, \\ IAIN Pekalongan \\ Email: agus.arwani@iainpekalongan.ac.id \\ Muhammad Wakhidin \\ Faculty of Islamic Economics and Business, \\ IAIN Pekalongan \\ Email: wahidsurya02@gmail.com
}

\section{ARTICLE HISTORY}

Received:

6 Oktober 2018

Accepted:

1 November 2018

Online available:

2 November 2018

Keywords:

Company size, Investment Return, Provitability, Solvency, Islamic Insurance

\section{ABSTRACT}

The purpose of this study is to determine the effect of partial and simultaneous Company Size, Investment Return, and Profitability on Solvency with proxy of RBC at Sharia Insurance in Indonesia period 2012-2016. This study uses a quantitative approach. Sampling technique is purposive sampling and there were 17 sharia general insurance and sharia life insurance company in Indonesia as subject of research. Analysis technique used is panel data regression by using Fixed Effect Model (FEM). The results of this study indicate that simultaneously company size, investment return, and profitability significantly influence the solvency of Takaful insurance in Indonesia. And partially variable of company size have positive and significant influence, variable investment return has no significant effect, and variable of profitability has no significant effect to solvency of sharia life insurance in Indonesia period 2012-2016.

\section{ABSTRAK}

Kata Kunci:

Ukuran

Perusahaan, Hasil

Investasi,

Profitabilitas,

Solvabilitas,

Asuransi Syariah
Pembiayaan merupakan elemen yang penting dalam proses bisnis perbankan. Berdasarkan data Bank Indonesia, produk pinjaman yang paling dibutuhkan adalah murabahah dengan menggunakan prinsip jual-beli. Tujuan penelitian ini adalah untuk menemukan pengaruh pembiayaan Murabahah, Ijarah terhadap profit BCA Syariah secara simultan dan parsial pada tahun 2012-2015. Jenis penelitian ini adalah jenis penelitian kuantitatif. Sumber data berasal dari laporan keuangan bulanan dari Januari 2012 hingga Desember 2015. Analisis data ini menggunakan t-test yang 
mengindikasikan bahwa variabel pembiayaan Murabahah memiliki pengaruh yang signifikan pada profit sebesar kurang dari $5 \%$ atau sama dengan 0.000 dan untuk variabel ijarah tidak memiliki pengaruh signifikan pada pendapatan atau sama dengan 0.374. Berdasarkan hasil uji $\mathrm{F}$, dapat disimpulkan bahwa pembiayaan Murabahah dan ljarah memiliki pengaruh terhadap profit BCA Syari'ah. Tingkat signifikansi variabel berdasarkan dari uji $\mathrm{F}$ menunjukkan bahwa lebih kecil dari level signifikansi 5\% atau $0,00 \mathrm{m0}$. Tingkat akurasi dalam estimasi variabel independen terhadap variabel dependen adalah sebesar 59,1\% sedangkan sisanya sebesar $40,9 \%$ dipengaruhi oleh variabel lainnya.

\section{INTRODUCTION}

Islamic banks are a form of modern banking that is based on Islamic law is legitimate. , Contributions to participate in the public welfare, the role of Islamic banks in performing its social function. The social function of the most visible of which is manifested in the form of activity of collection and distribution of zakat, donation, charity, donation and waqf. Besides Islamic banks also issue a zakat of operating profit as well as provide financing virtue (qardh).

Funds collected from the community bank channeled back in the form of financing based on Islamic principles. Funding is the highest level of income for banks. The income level of each type of financing varies, depending on the financial principles used and the business sector financed.

One of the leading Islamic banks in Indonesia, BCA Syariah, which was originally named the Main Bank International. On December 16, 2009, Utama PT Bank International officially changed to PT Bank BCA Syariah.

Based on the financial report published on the official website of BCA Syariah, in 2013 BCA sharia showed remarkable improvement. The company's net profit in 2012 reached 8.2 billion rupiahs, while in 2013 profit rose dramatically to reach 12.5 billion rupiahs in 2014 continued to increase the rate of profit reached 13.1 billion rupiahs. The profit was increased significantly in 2015 that touched the figure of 23.8 billion rupiahs.

Earnings were successfully obtained by the bank, not in spite of the success of financing products successfully sold to the public. Based on data from Bank Indonesia, the products most in demand public financing is Murabaha. Murabahah is a sale of goods in addition to the price of the original price as an advantage that has been agreed. ljarah 
itself as a financing product that is not too well known by the public, but it affects the profitability of Islamic banks.

Based on the description above, Murabaha and ljarah financing cannot be in one eye view, both products have shown the existence of such financing in various banks, as has been done by previous researchers. Thus the researchers conducted this study with the formulation of the problem: 1) Is the effect on profit Murabaha financing BCA Syariah? 2) What is the effect on profit ljara financing BCA Syariah? 3) Are the financing Murabaha and ljarah simultaneous effect on earnings BCA Syariah?

\section{LITERATURE REVIEW}

In the Islamic banks, financing means that the bank's activities in channeling funds to the public or any party other than banks based on Islamic principles. The distribution of funds in the form of financing based on the trust given by the owner of the funds to the fund, that the funds provided in the form of financing will certainly pay off. Grantees also have an obligation to repay the funds it has received financing in accordance with the time period specified in the agreement financing agreement.

In law No. 21 of 2008 concerning Sharia Banking paragraph 1 letter d, mentioned that Murabaha is an asset and the financing agreement confirms the purchase price to the buyer and the buyer paid a higher price as agreed profit.

ljara word comes from the Arabic language which means replace, lease, or wages. The understanding in Personality 'is a type of contract in the form of benefit by the replacement. In another sense, as the transfer of rights to contract for goods or services through a lease payment of wages.

Earnings is net income as seen from the difference between the total income of the company with the total cost. The net profit derived from the transaction revenues, expenses, gains, and losses. These transactions are summarized in the consolidated statement loss. Accountants have adopted the approach of transaction (Transaction approach) in measuring profit or net loss, which emphasizes the direct calculation of revenues, expenses, gains and losses

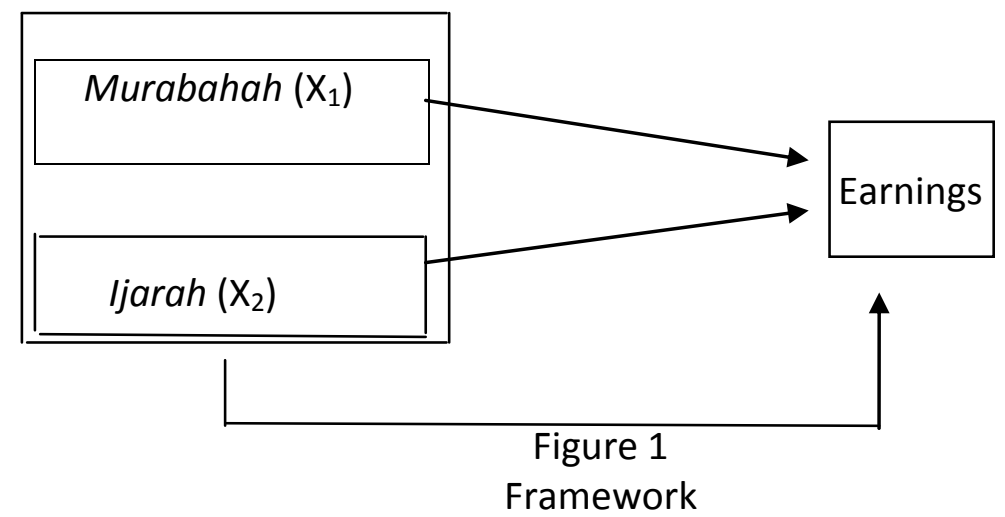


Based on the theoretical basis and framework described earlier, the research hypothesis can be formulated as follows:

$\mathrm{H}_{1}$ : Murabahah Financing effect on earnings.

$\mathrm{H}_{2}$ : ljara Financing effect on earnings.

$\mathrm{H}_{3}$ : Financing Murabahah and ljarah simultaneously affect the profit.

\section{RESEARCH METHODS}

This research is causal research comparative research that determines the cause, effect or consequence that exists between two or more variables. In this study, the independent variables are Murabaha $\left(X_{1}\right)$ and ljara $\left(X_{2}\right)$ with the dependent variable is Earnings ( $\mathrm{Y}$ ).

This research is a quantitative research, the research uses numbers as the data later in the analysis were generally use statistics.

By way of acquiring it, data is grouped into two primary data and secondary data. Primary data is data obtained by the individual or organization directly from the object. While secondary data is data obtained in the form of publications, such as the company's financial statements, the data of magazines, journals, websites, and others. The type of data in this study included secondary data types.

According to the problem under study, the source of the data used in this research is secondary data in the form of financial statements BCA sharia taken from the official website of BCA Syariah namely www.bcasyariah.com.

Analysis model used in this study using multiple linear regression equations as follows:

$Y=a+b_{1} X_{1}+b_{2} X_{2}+\varepsilon$

Where:

$\mathrm{Y} \quad=$ Earnings

a $=$ constant $(Y$ value when the value of $X=0)$

$\mathrm{b} 1-\mathrm{b} 2=$ regression coefficient of each independent variable

$\mathrm{X}_{1}=$ Murabahah

$\mathrm{X}_{2}=$ ljarah Financing

$\varepsilon=$ Error

Prior to the analysis, it will first performed classical assumption, which includes data normality test, multicollinearity, autocorrelation, and heteroscedasticity.

\section{RESULT AND DISCUSSION}

\section{Descriptive analysis}

Table 1

Results Descriptive Statistics Analysis

Descriptive Statistics

$\mathrm{N}$ Minimum Maximum Mean Std. Deviation


Murabahah Financing And Effect On Earnings....

\begin{tabular}{cccccc}
\hline Murabahah & 48 & 308120.00 & 1450606.00 & 677935.4375 & 345172.85351 \\
\hline ljarah & 48 & 60143.00 & 182025.00 & 117469.1458 & 39571.59989 \\
\hline Earnings & 48 & 124.00 & 3123.00 & 1204.7917 & 706.68275 \\
\hline Valid N (listwise) & 48 & & & & \\
\hline
\end{tabular}

Source: SPSS output data 22

From the results of descriptive statistics in the table above, shows that the amount of research data on the Bank's Sharia during the period 2012-2015 as much as 48 data. In this study, there is one dependent variable and two independent variables. The dependent variable consisting of Murabaha financing $\left(X_{1}\right)$ and ljara $\left(X_{2}\right)$, while the independent variable is Earnings $(\mathrm{Y})$.

During the years 2012-2015, the average number of Murabaha financing of Rp. Rp. $677,935.44$ million. The maximum value of Murabaha financing occurred in December 2015 by the number of Murabaha financing of Rp 1,450,606 million, while the minimum value of Murabaha financing occurred in April 2012 with the number of Murabaha financing of Rp. 308120 million. Standard deviation Murabaha financing of Rp. 345,172.85 million.

During the years 2012-2015, the average amount of financing ljarah amounting to Rp. 117,469.15 million. The maximum value of ljara financing occurred in November 2015 by the amount of financing ljarah amounting to Rp. 182025 million, while the minimum value of ljara financing occurred in June 2013, with the amount of financing ljarah amounting to Rp. 60143 million. Standard deviation ljara financing of Rp. 39571.60 million.

During the years 2012-2015, the average amount of profit of Rp. 1204.79 million. The maximum value of $\mathrm{Rp}$. 3,123 million, which occurred in December 2015. The minimum income occurred in March 2012 with a profit of Rp. 124 million. Standard deviation profit of Rp. 706.68 million.

\section{Classic assumption test}

Normality test

Table 2

One - Sample Kolmogorov-Smirnov Test

\begin{tabular}{|c|c|c|}
\hline \multicolumn{3}{|c|}{ One-Sample Kolmogorov-Smirnov Test } \\
\hline & & $\begin{array}{l}\text { Unstandardize } \\
\text { d Residual }\end{array}$ \\
\hline $\mathrm{N}$ & & 48 \\
\hline \multirow[t]{2}{*}{ Normal Parameters $^{a}$} & Mean & .0000000 \\
\hline & Std. Deviation & 442.45969474 \\
\hline \multirow{2}{*}{$\begin{array}{l}\text { Most } \\
\text { Differences }\end{array}$} & Extreme Absolute & .115 \\
\hline & Positive & .115 \\
\hline
\end{tabular}




\begin{tabular}{|c|c|}
\hline Negative & -.093 \\
\hline Kolmogorov-Smirnov Z & .796 \\
\hline Asymp. Sig. (2-tailed) & .551 \\
\hline
\end{tabular}

Source: Analysis of the results of data SPSS 22

Based on Table 4.2 shows that the KS value of 0.796 with a significance of 0.551 . These data show the normal distribution for a significant value greater than the value of 0.05 $(0.551>0.05)$. Thus, it can be stated that the residuals are normally distributed.

\section{Multicollinearity Test}

Table 3

Multicollinearity Test

\begin{tabular}{|c|c|c|c|}
\hline \multicolumn{4}{|c|}{ Coefficients } \\
\hline & & \multicolumn{2}{|c|}{ Collinearity Statistics } \\
\hline \multicolumn{2}{|l|}{ Model } & Tolerance & VIF \\
\hline \multirow[t]{3}{*}{1} & (Constant) & & \\
\hline & Murabahah & .435 & 2.300 \\
\hline & ljarah & .435 & 2.300 \\
\hline
\end{tabular}

a. Dependent Variable: earnings

Source: The results of data analysis SPSS 22

The test results showed none of the independent variables that have a VIF value of more than 10 and no one has a tolerance smaller than 0.1. The analysis results obtained VIF Murabaha financing amounted to 2,300, ljara financing amounted to 2,300. So we can conclude multicollinearity not occur between independent variables in the regression model of this study.

\section{Test Heteroskedasticity}

Table 4

Glejser Test

\begin{tabular}{|c|c|c|c|c|c|c|}
\hline & \multicolumn{6}{|c|}{ Coefficients } \\
\hline & \multirow[b]{2}{*}{ Model } & \multicolumn{2}{|c|}{$\begin{array}{c}\text { Unstandardized } \\
\text { Coefficients }\end{array}$} & \multirow{2}{*}{$\begin{array}{c}\begin{array}{c}\text { Standardized } \\
\text { Coefficients }\end{array} \\
\text { Beta }\end{array}$} & \multirow[b]{2}{*}{$\mathrm{t}$} & \multirow[b]{2}{*}{ Sig. } \\
\hline & & B & Std. Error & & & \\
\hline \multirow[t]{3}{*}{1} & (Constant) & 313.701 & 136.605 & & 2.296 & .026 \\
\hline & murabahah & $-4.853 E-5$ & .000 & -.058 & -.255 & .800 \\
\hline & ljarah & .000 & .002 & .057 & .253 & .801 \\
\hline
\end{tabular}

a. Dependent Variable: Abs earnings 
Source: The results of data analysis SPSS 22

From the results of SPSS output above shows that the Murabaha and ljarah both have more significance level of 0.05. Due to the significance level over 0.05, it can be inferred that the regression model does not contain any heteroscedasticity.

\section{Autocorrelation Test}

Table 5

Durbin-Watson test

\begin{tabular}{llllll}
\hline \multicolumn{6}{c}{ Model Summary } \\
\hline Model R & R Square & $\begin{array}{l}\text { Adjusted } \\
\text { Square }\end{array}$ & $\begin{array}{l}\text { R Std. Error of Durbin- } \\
\text { the Estimate }\end{array}$ Watson \\
\hline 1 & $.780^{\mathrm{a}}$ & .608 & .591 & 452.18525 & 1.646 \\
\hline
\end{tabular}

a. Predictors: (Constant), ljarah, Murabahah

b. Dependent Variable: earnings

Source: The results of data analysis, SPSS 22

With $\mathrm{n}=48$ and $\mathrm{k}=2$ then when seen in the table Durbin-Watson value, obtained $\mathrm{dl}=$ 1.4500 and $d u=1.6231$, so the value of $4-d U$ at 4 to $1.6518=2.5500$. Based on the above table, the Durbin-Watson value of 1,646 and is the area between $\mathrm{dU}<\mathrm{d}<4-\mathrm{dU}(1.4500$ $<1.646<2.5500)$, it can be concluded that the regression model no symptoms of autocorrelation either positively or negatively.

Multiple Regression Analysis

Table 6

Regression coefficients

\begin{tabular}{|c|c|c|c|c|c|c|}
\hline & \multirow[b]{3}{*}{ Model } & \multicolumn{5}{|c|}{ Coefficients } \\
\hline & & \multicolumn{2}{|c|}{$\begin{array}{l}\text { Unstandardized } \\
\text { Coefficients }\end{array}$} & \multirow{2}{*}{$\begin{array}{c}\text { Standardized } \\
\text { Coefficients } \\
\text { Beta }\end{array}$} & \multirow[b]{2}{*}{$\mathrm{T}$} & \multirow[b]{2}{*}{ Sig. } \\
\hline & & $B$ & Std. Error & & & \\
\hline \multirow[t]{3}{*}{1} & (Constant) & 262.836 & 208.117 & & 1.263 & .213 \\
\hline & murabahah & .002 & .000 & .871 & 6.152 & .000 \\
\hline & ljarah & -.002 & .003 & -.127 & -.898 & .374 \\
\hline
\end{tabular}

a. Dependent Variable: earnings

Source: The results of data analysis, SPSS 22

Profit $=262836+0,002$ Murabaha $+(-0.002)$ ljara

Based on the above equations do the following interpretation. 
1. The value of a constant or $a=262836$ means that if the financing Murabaha and ljarah equal to zero, then the profit for the year 2012-2015 on sharia BCA will increase by Rp. 262836.

2. The regression coefficient or $b 1=0.002$ means that any increase in Murabaha financing of Rp 1 million will be able to increase earnings in 2012-2015 on sharia BCA Rp. 2,000.

3. The regression coefficient or b2 $=-0.002$ means that any increase in ljara Rp 1 million will reduce profit for the year 2012-2015 on sharia BCA Rp 2000.

\section{Significance test}

\begin{tabular}{|c|c|c|c|c|c|}
\hline \multicolumn{6}{|c|}{$\begin{array}{l}\text { Table } 7 \\
\text { t-test }\end{array}$} \\
\hline \multicolumn{6}{|c|}{ Coefficients } \\
\hline \multirow[b]{2}{*}{ Model } & \multicolumn{2}{|c|}{$\begin{array}{l}\text { Unstandardized } \\
\text { Coefficients }\end{array}$} & \multirow{2}{*}{$\begin{array}{l}\text { Standardized } \\
\text { Coefficients } \\
\text { Beta }\end{array}$} & \multirow[b]{2}{*}{$\mathrm{T}$} & \multirow[b]{2}{*}{ Sig. } \\
\hline & $B$ & Std. Error & & & \\
\hline 1 (Constant) & 262.836 & 208.117 & & 1.263 & .213 \\
\hline Murabahah & .002 & .000 & .871 & 6.152 & .000 \\
\hline ljarah & -.002 & .003 & -.127 & -.898 & .374 \\
\hline $\begin{array}{l}\text { a. Dependent } \\
\text { earnings }\end{array}$ & Variable & & & & \\
\hline
\end{tabular}

Source: The results of data analysis, SPSS 22

Based on the test results of the above statistics, testing the hypothesis is as follows:

a. Murabahah financing

T-count Murabaha financing amounted to 6.152 with a significance level of 0.000 . In this study using $\alpha$ level of $5 \%$, due to the level of significance $0.000<0.05$ (significance smaller than $\alpha$ ), then the $\mathrm{H} 1$ accepted meaning of Murabaha financing sharia BCA effect on earnings.

b. ljarah financing

T-count ljarah financing amounting to -0.898 with a significance level of 0.374 . A level in this study by $5 \%$, due to the level of significance $0.374>0.05$ (significance is greater than $\alpha$ ), the $\mathrm{H} 2$ is rejected, it means ljara financing has no effect on earnings BCA sharia.

\begin{tabular}{|c|c|c|c|c|c|}
\hline \multicolumn{6}{|c|}{$\begin{array}{c}\text { Table } 8 \\
\text { Test F }\end{array}$} \\
\hline \multicolumn{6}{|c|}{ ANOVA $^{\mathrm{b}}$} \\
\hline Model & $\begin{array}{l}\text { Sum of } \\
\text { Squares }\end{array}$ & Df & Mean Square & $\mathrm{F}$ & Sig. \\
\hline
\end{tabular}




\begin{tabular}{|c|c|c|c|c|c|c|}
\hline \multirow[t]{3}{*}{1} & $\begin{array}{c}\text { Regressi } \\
\text { on }\end{array}$ & 1.427E7 & 2 & 7135303.294 & 34.896 & $.000^{\mathrm{a}}$ \\
\hline & Residual & 9201217.329 & 45 & 204471.496 & & \\
\hline & Total & $2.347 \mathrm{E} 7$ & 47 & & & \\
\hline \multicolumn{4}{|c|}{$\begin{array}{c}\text { a. Predictors: (Constant), ljarah, } \\
\text { Murabahah }\end{array}$} & & & \\
\hline \multicolumn{4}{|c|}{ b. Dependent Variable: earnings } & & & \\
\hline
\end{tabular}

Source: The results of data analysis, SPSS 22

From the results in Table 4.7 that the output value of Fhitung 28.347 with a significance level of 0.000 . A level in this study by $5 \%$, due to the level of significance $0.000<0.05$ (significance smaller than $\alpha$ ), the $\mathrm{H} 3$ is accepted, meaning that there is a simultaneous influence of Murabaha financing (X1), and ljarah (X2) to profit ( $\mathrm{Y}$ ) at BCA sharia.

The coefficient of Determination

Table 9

The coefficient of Determination

\begin{tabular}{|c|c|c|c|}
\hline \multicolumn{4}{|c|}{ Model Summary } \\
\hline Model R & R Square & $\begin{array}{l}\text { Adjusted } \\
\text { Square }\end{array}$ & $\begin{array}{l}\text { R Std. Error of Durbin- } \\
\text { the Estimate Watson }\end{array}$ \\
\hline $1 \quad .780^{\mathrm{a}}$ & .608 & .591 & 452.18525 \\
\hline \multicolumn{4}{|c|}{ a. Predictors: (Constant), ljarah, Murabahah } \\
\hline \multicolumn{4}{|c|}{ b. Dependent Variable: earnings } \\
\hline
\end{tabular}

The above table shows that the value of adjusted $R 2$ of 0.591 or $59.1 \%$ earnings $(Y)$. This means the amount of profit can be explained by the variable Murabaha financing $(X 1)$ and ljara financing (X2) amounted to $59.1 \%$. While the rest $(100 \%-59.1 \%=40.9 \%)$ can be explained by other variables not examined in this study.

1. Analysis

1. Effect of Murabahah to Earnings

T-count Murabaha financing amounted to 6.152 with a significance level of 0.000 . In this study using $\alpha$ level of $5 \%$, due to the level of significance $0.000<0.05$ (significance smaller than $\alpha$ ), then $\mathrm{H}_{1}$ accepted, meaning Murabaha financing effect on earnings in the BCA sharia.

Financing is managed properly will prevent the banks from the risk of bad debts, so that payment of the price of goods and their margins have been established and agreed upon by the bank and the debtor, will go to the bank. The Margin is what will be the bank's profits.

2. Effect of ljarah Financing to Earnings 
Account ljarah financing amounting to -0.898 with a significance level of 0.374 . A level in this study by $5 \%$, due to the level of significance $0.374>0.05$ (significance is greater than $\alpha$ ), the $\mathrm{H}_{2}$ is rejected, it means ljara financing does not affect the profit of the Bank of sharia.

When viewed from the financial statements as indicated on the previous page, it can be analyzed that from year to year ljara financing of up and down. In 2012 the average ljara financing of 100 billion rupiahs. While in 2013 and 2014 ljarah financing decreased. In 2015, Murabaha financing increased again. On the other hand, though ljara financing has decreased in 2013 and 2014, BCA's earnings sharia continued to rise. This is one reason why the ljara financing has no effect on earnings.

3. Effect of Murabahah and ljarah Financing to Earnings

Simultaneously value Fhitung 28.347 with a significance level of 0.000 . A level in this study by $5 \%$, due to the level of significance $0.000<0.05$ (significance smaller then $\alpha$ ), the $\mathrm{H} 3$ is accepted, meaning that there is a simultaneous influence of Murabaha financing $\left(X_{1}\right)$, and ljarah $\left(X_{2}\right)$ to profit $(Y)$ at BCA sharia.

In banks, they're earning assets and non-earning assets. Productive assets are an investment bank in the rupiah currency and in foreign currency, in the form of financing, securities, interbank placements, investment, including commitments and contingencies in administrative account transactions. Earning assets to work to earn income on the funds disbursed by the bank. However, the placement of funds in the form of productive assets also has risks, namely the risk of funds channeled not return, causing loss to the bank.

\section{CONCLUSION}

Number of Murabaha financing a significant effect on the amount of profit. The number of ljara financing does not affect the amount of profit. Murabahah and ljarah simultaneously significant effect on the dependent variable (profit). So, for the bank, it should increase the amount of financing and supervise in order to avoid bad credit. So it can be profitable for banks. Recpomendation for next researchers further is recommended adding variables corresponding research provided in the financial statements of banks. Besides, always do research with the latest in current research is conducted. Note also the readiness of the researchers of the research object.

\section{REFERENCES}

Antonio, Muhammad Syafi'i. (2001). Bank Syariah dari Teori ke Praktik. Jakarta: Gema Insani.

Arifin, Zainul. (2005). Dasar-dasar Manajemen Bank Syariah. Jakarta: Pustaka Alvabet. 
Ariyani, Dinna. (2014). Analisis Pengaruh Pertumbuhan Pembiayaan Murabahah, Bagi Hasil dan Pinjaman Qardh terhadap Pertumbuhan Laba Bersih pada Bank Syariah Periode Triwulan I 2011 sampai Triwulan IV 2013. Jurnal dari www.jurnal.umrah.ac.id diakses tanggal 07 oktober 2015.

Ascarya. (2007). Akad dan Produk Bank Syariah. Jakarta: PT Raja Grafindo.

Asiyah, Binti Nur. (2014). Manajemen Pembiayaan Bank Syariah. Yogyakarta: Teras.

Dahlan, Ahmad. (2012). Bank Syariah Toritik, Praktik, Kritik. Yogyakarta:Sukses Offset.

Ghozali, Imam. (2011). Aplikasi Analisis Multivariate dengan Program IBM SPSS 19. Semarang: Badan Penerbit Universitas Diponegoro.

Greuning, Hennie van dan Zamir Iqbal.(2011). Analisis Risiko Perbankan Syariah Jakarta: Salemba Empat.

Hadi, Syamsul. (2006). Metodologi Penelitian Kuantitatif untuk Akuntansi dan Keuangan. Yogyakarta: Ekonisia.

Haroen, Nasrun. (2007). Fiqh Muamalah. Jakarta: Gaya Media Pratama.

Hery. (2012). Akuntansi Keuangan Menengah. Jakarta: Bumi Aksara.

Iska, Syukri. (2014). Sistem Perbankan Syariah di Indonesia dalam Perspektif Fikih Ekonomi. Yogyakarta: Fajar Media Press.

Ismail. (2010). Akuntansi Bank: Teori dan Aplikasi dalam Rupiah. Jakarta: Kencana Prenada Grup.

Ismail. (2014). Perbankan Syariah. Jakarta: Kencana Prenada Media Grup.

Karim, Adiwarman. (2001). Bank Islam: Analisa Fiqih dan Keuangan. Jakarta: Raja Grapindo Persada.

Martono, Nanang. (2010). Metodologi Penelitian Kuantitatif Analisis Isi dan Analisis Data Sekunder. Jakarta: PT Raja Grafindo Persada.

Masyhuri dan Muhammad Zainudin. (2011). Metodologi Penelitian Praktis dan Aplikatif. Bandung: PT Refika Aditama.

Muhammad. (2004). Manajemen Dana Bank Syariah. Yogyakarta: Ekonisia.

Muthaher, Osmad. (2012). Akuntansi perbankan Syariah. Yogyakarta: Graha Ilmu.

Narbuko, Cholid dan Abu Achmadi. (2013). Metodologi Penelitian. Jakarta: PT Bumi Aksara.

Permana, Hardi Dwi. (2014). Pengaruh Struktur Pembiayaan (Prinsip Bagi Hasil, Jual Beli, dan Sewa) terhadap Kinerja Keuangan pada PT Bank Muamalat Indonesia. Skripsi Ekonomi Universitas Syiah Kuala Darussalam Banda Aceh. 
Purwanto, Erwan Agus dan Dyah Ratih Sulistyastuti. (2011). Metode Penelitian Kuantitatif untuk Administrasi Publik dan Masalah-masalah Sosial. Yogyakarta: Gava Media.

Rahman, Aulia Fuad dan Ridha Rochmanika, (2013). "Pengaruh Pembiayaan Jual Beli, Pembiayaan Bagi Hasil, dan Rasio Non Performing Financing terhadap Profitabilitas Bank Umum Syariah Indonesia", Malang: Jurnal Ekonomi dan Bisnis Universitas Brawijaya.

Saeed, Abdullah. (2004). Bank Islam dan Bunga. Yogyakarta:Pustaka Pelajar.

Sjahdeini, Sutan Remy. (2014). Perbankan Syariah Produk-produk dan Aspek-aspeknya. Jakarta:Kencana Prenadamedia Group.

Soemitra, Andri. (2009). Bank dan Lembaga Keuangan Syariah. Jakarta: Kencana.

Sudarsono, Heri. (2007). Bank dan Lembaga Keuangan Syariah Deskripsi dan Ilustrasi Yogyakarta: Ekonosia.

Suharsaputra, Uhar. (2012). Metodologi Penelitian Kuantitatif, Kualitatif dan Tindakan. Bandung: PT Refika Aditama.

Sukandarrumidi. (2012). Metodologi Penelitian Petunjuk Pr aktis Untuk Peneliti Pemula. Yogyakarta: Gadjah Mada University Press.

Sumar'in. (2012). Konsep Kelembagaan Bank Syariah. Yogyakarta: Graha IImu.

Sutanto, Herry dan Kherul Umam. (2013). Manajemen Pemasaran Bank Syariah. Bandung: CV Pustaka Setia

Umam, Khaerul. (2013). Manajemen Perbankan Syariah. Bandung: CV Pustaka Setia.

Umar, Husein. (2009). Metodologi Penelitian untuk Skripsi dan Tesis Bisnis. Jakarta: PT Raja Grafindo Persada.

Utami, Noor Fakhria. (2014). Pengaruh Pembiayaan Jual Beli, Pembiayaan Bagi Hasil, Pembiayaan Sewa terhadap Kinerja Keuangan Bank Syariah Mandiri, Skripsi Keuangan Islam UIN Sunan Kalijaga Yogyakarta.

www.bcasyariah.com

Yulianfitri, Indri. (2011). “Analisis Faktor-faktor yang Mempengaruhi Laba dan Arus Kas Masa Depan Pada Perusahaan Go Public". Jurnal Investasi: Vol VII No 7.

Yusuf, Muri.. (2014). Metodologi Penelitian Kuantitatif, Kualitatif dan Peneltian Gabungan. Jakarta: Kencana.

Ziqri, Muhammad. (2009). "Analisis Pengaruh Pendapatan Murabahah, Mudharabah, dan Musyarakah terhadap Profitabilitas Bank". Jakarta: Skripsi Ekonomi dan IImu Sosial. 